bioRxiv preprint doi: https://doi.org/10.1101/2021.05.22.445288; this version posted May 23, 2021. The copyright holder for this preprint (which was not certified by peer review) is the author/funder, who has granted bioRxiv a license to display the preprint in perpetuity. It is made available under aCC-BY 4.0 International license.

\title{
REGULAR ARTICLE \\ DIRECT DETECTION OF LISTERIA MONOCYTOGENES BY RECOMBINASE POLYMERASE AMPLIFICATION
}

\author{
Hau Thi Tran, Diem Hong Tran, Trang Nguyen Minh Pham, Huong Thi Thu Phung* \\ Address: \\ NTT Hi-Tech Institute, Nguyen Tat Thanh University, 298A Nguyen Tat Thanh, Ho Chi Minh City, 700000, Vietnam, +84981411701.
}

*Corresponding author: ptthuong@ntt.edu.vn

\begin{abstract}
Listeria monocytogenes is one of the most common types of food poisoning bacteria which can cause serious foodborne diseases or even lethality. Generally, L. monocytogenes can be detected using traditional microbiology or molecular biology techniques, notably PCR However, the application of these methods at the field is restricted due to the strict requirement of equipment and skilled personnel. In this study, recombinase polymerase amplification (RPA), an isothermal PCR assay was developed to rapidly detect L. monocytogenes in the crude samples. The results showed that the RPA reaction, without requiring complex thermal cycles, was well-performed in the optimal conditions of $39^{\circ} \mathrm{C}$ within only 25 minutes. The limit of detection was identified as $310 \mathrm{fg}$ of L. monocytogenes genomic DNA, which was 1000 -fold more sensitive than the conventional PCR. In addition, RPA also succeeded to directly detect L. monocytogenes cells at a concentration as low as $2.5 \times 10^{1}$ Colony Forming Unit $(\mathrm{CFU}) / \mathrm{ml}$ in pure cultures and $2.5 \times 10^{2} \mathrm{CFU} / \mathrm{ml}$ in crude samples without sample extraction or processing. Therefore, RPA established in this study could be an alternative standard method to confirm the presence of $L$. monocytogenes in food. Accordingly, this rapid and sensitive method could be further applied to clinical testing for the diagnosis of $L$. monocytogenes infection, especially in areas with limited settings.
\end{abstract}

Keywords: Listeria monocytogenes, direct RPA, foodborne diseases, rapid detection, isothermal PCR

\section{INTRODUCTION}

Listeria monocytogenes is a Gram-positive, rod-shaped, facultatively anaerobic and non-sporulating bacterium, which is the causative agent of human listeriosis, a rare foodborne infectious disease with high hospitalization and case lethality rates ( Gandhi \& Chikindas, 2007; Carvalho et al., 2014). The major sources of $L$. monocytogenes infection were unpasteurized milk or soft cheese made from raw milk. Besides, consumption of the ready-to-use meat contaminated was also considered as an important risk source of the L. monocytogenes infection (Swaminathan \& Gerner-Smidt, 2007). In 2018, an outbreak of listeriosis was reported with 978 confirmed cases in South Africa. Most of the cases are neonates, pregnant women, the elderly, and immunocompromised persons (WHO, 2018). In Vietnam, the serious consequences of human listeriosis infection causing meningitis were reported as well (Chau et al., 2010).

Commonly, L. monocytogenes can be detected using traditional microbiology or biomolecular techniques. The traditional microbiological methods for detecting L. monocytogenes are quite time-consuming and sophisticated (Curtis \& Lee, 1995). A suitable culture media is required for the growth of $L$. monocytogenes and an identified step was performed with some complex biochemical assays before isolating $L$. monocytogenes from cultures (Taherkhani et al., 2013). In recent decades, PCR was considered as an effective molecular method to alternate the conventional microbiological method to detect different bacterial pathogens including L. monocytogenes (Göksoy \& Kaya, 2006; Swetha et al., 2016). The method has significant improvements in sensitivity and specificity. However, PCR requires an accurate thermal cycler and a considerable running time while the application of the standard operating procedure for PCR at point-of-care diagnosis is restricted (Delibato et al., 2009).

Recently, isothermal amplification approaches based on conventional PCR assay such as loop-mediated isothermal amplification (LAMP), cross-priming amplification (CPA), polymerase spiral reaction (PSR) and recombinase polymerase amplification (RPA) have been widely used in analyzing the foodborne organism pathogens ( Notomi et al., 2000; Craw \& Balachandran, 2012; Xu et al., 2012; Craw et al., 2013; W. Liu et al., 2015). LAMP, CPA and PSR assays were previously employed to detect L. monocytogenes (Wang et al., 2014; Du et al., 2018; Nathaniel et al., 2019). All of these methods were shown to have high sensitivity and specificity with the ideal limit of detection (LOD). Moreover, these assays are simpler, more rapid and cost-effective compared to conventional PCR.

LAMP, CPA, and PSR have been considered useful isothermal amplification techniques for the early diagnosis of L. monocytogenes. However, these methods usually require sets of specially designed primers for identifying distinct regions of the target sequence as well as higher incubation temperatures (Piepenburg $\boldsymbol{e t}$ al., 2006). The RPA assay possesses some advantages over the others because it requires only two specific primers and a lower incubation temperature to run the reaction. The amplification of nucleic acid in RPA is performed by a recombinase-primer complex. A DNA polymerase having a strand-displacement activity is utilized to extend the specific primers at cognate sites and the intermediate structures are stabilized by single-stranded DNA binding proteins. Additionally, the RPA reactions do not need a global melting step of the template, thus, the requirements of restricted equipment for RPA assay are not essential (Piepenburg et al., 2006). Nowadays, portable and compact lateral flow (LF) strips have already provided the ideal method for simple and rapid visualization of the RPA amplicon at the field (Daher et al., 2016). LF strips utilize hybridisation products as the substrate, for example RPA products and antigen-labelled probes. LF strips are labelled with an antibody specific to an antigen labelled on probes accordingly. Typically, amplicon can be detected by capture of antigen by anti-FAM and anti-Biotin antibodies, displaying a visual band on the strips (Daher et al., 2016). Additionally, RPA amplified product can be applied directly onto the dipstick strips without purification, generating results within merely 5 min afterward (Daher et al., 2016). Thus, the result can be read by the naked eye shortly. Therefore, combination with LF strips can minimize and simplize the detection procedure of RPA product in a resource-limited setting.

Previously, the RPA assays were successfully established to identify some types of food poisoning bacteria (Gao et al., 2017; Liu et al., 2017; Du et al., 2018; Geng et al., 2019; Hu et al., 2020). Previously, Gao et al. (2017) utilized RPA to detect $L$. monocytogenes successfully with a limit of detection (LOD) of $10 \mathrm{pg}$ of genomic DNA per reaction. However, they did not perform direct detection of L. monocytogenes cells in simulated samples. Later, Du et al. (2018) evaluated the RPA performance for detecting $L$. monocytogenes with the LOD of $300 \mathrm{fg}$ of genomic DNA and 1.5 Colony Forming Unit (CFU) in spiked food samples. Nevertheless, their approach required sample enrichment for 6 hours. Therefore, in this study, we attempted to establish a direct RPA assay for rapid and accurate detection of L. monocytogenes cells in the unprocessed food sample. The simply operational mechanism, the isothermal establishment and the short testing time make the RPA assay developed more accessible to limited setting areas. 
bioRxiv preprint doi: https://doi.org/10.1101/2021.05.22.445288; this version posted May 23, 2021. The copyright holder for this preprint (which was not certified by peer review) is the author/funder, who has granted bioRxiv a license to display the preprint in perpetuity. It is made available under aCC-BY 4.0 International license.

\section{MATERIAL AND METHODS}

\section{Bacterial cultivation}

L. monocytogenes (laboratory collection) was cultured overnight at $37^{\circ} \mathrm{C}$ in Brain Heart Infusion broth (HiMedia Laboratories Pvt. Ltd, India). Through shaking bacterial cultures at 180 rounds per $\min (\mathrm{rpm})$, precipitation of cells was avoided. Other bacterial strains (laboratory collection) including Salmonella enterica, Staphylococcus aureus, Clostridium perfringens, Bacillus cereus, and Vibrio parahaemolyticus were cultured similarly.

\section{DNA extraction}

The cetrimonium bromide (CTAB) extraction buffer contains $2 \%(\mathrm{w} / \mathrm{v}) \mathrm{CTAB}, 100 \mathrm{mM}$ Tris- $\mathrm{HCl}(\mathrm{pH} 8), 20 \mathrm{mM}$ EDTA (pH 8), $1.4 \mathrm{M}$ $\mathrm{NaCl}$. The L. monocytogenes cells were harvested from $1 \mathrm{ml}$ of culture by centrifugation, and supernatants were then discarded. Cells were resuspended in $800 \mu \mathrm{l}$ of the pre-warmed $\left(65^{\circ} \mathrm{C}\right) \mathrm{CTAB}$ lysis buffer and mixed thoroughly, then incubated at $65^{\circ} \mathrm{C}$ for $60 \mathrm{~min}$. Samples were then centrifuged at $4^{\circ} \mathrm{C}$ for $15 \mathrm{~min}$ at $14000 \mathrm{~g}$. Supernatants were transferred to fresh tubes and an approximately equal volume of Phenol: Chloroform: Isoamyl alcohol (PCI) was added and mixed thoroughly. Phase separation occurred by centrifugation at $14000 \mathrm{~g}$ for $15 \mathrm{~min}$ at $4^{\circ} \mathrm{C}$. The upper aqueous phases were moved to new tubes and a 2.5 equal volume of ethanol $99 \%$ was added. DNA was precipitated overnight at $-20^{\circ} \mathrm{C}$. The DNA was then dissolved with $50 \mu 1$ of elution buffer. The concentration and purification of DNA were measured with a Genova Plus Spectrophotometer (Jenway, Staffordshire, UK). The extracted genomic DNA was then stored at $-20^{\circ} \mathrm{C}$ until use.

Primer design

The RPA primers targeting the plcA gene of L. monocytogenes (Gene bank: CP023861.1) were designed according to the guidelines provided by TwistDx (Cambridge, UK) (http://hdl.handle.net/20.500.11794/26269). The primer set was chosen by assessing the specificity using NCBI BLAST and the amplification effects were also evaluated practically. In silico PCR analysis function available in FastPCR software (http://primerdigital.com/fastpcr.html) was additionally utilized for primer specificity analysis. The primer sequences were aligned to the reference genome sequences of other strains downloaded from NCBI. Two candidate primer pairs were commercially synthesized by IDT (Singapore). The primer pairs that produced the clearly visible bands representing for amplified product in agarose gel electrophoresis were selected and the sequences were listed in Table 1.

Table 1. Primer sequence for L. monocytogenes RPA assay

\begin{tabular}{lc}
\hline Name & Sequence (5'-3') \\
\hline$p l c A-\mathrm{F}$ & CCCATTAGGCGGAAAAGCATATTCGCTTAATA \\
plcA-R & CCTGCTTCTAGTTGTTGGTACAATGACATCG
\end{tabular}

\section{PCR reaction}

The PCR was carried out in a reaction volume of $20 \mu \mathrm{l}$ in small tubes containing $0.4 \mu \mathrm{M}$ each of RPA primers, $4 \mu 1$ of $5 \mathrm{X}$ Mytaq reaction buffer (Bioline, London, UK), $0.2 \mu \mathrm{l}$ of MyTaq DNA polymerase (Bioline, London, UK) and $1 \mu 1$ of DNA template. The PCR reaction was run as follows: initial denaturation stage at $95^{\circ} \mathrm{C}$ for 2 min, 35 cycles of $95^{\circ} \mathrm{C}$ for 30 seconds, $58^{\circ} \mathrm{C}$ for 30 seconds, $72^{\circ} \mathrm{C}$ for 30 seconds, and final extension stage at $72^{\circ} \mathrm{C}$ for $10 \mathrm{~min}$. The PCR results were analyzed by a $1.5 \%$ agarose gel electrophoresis.

RPA reaction for detection of $L$. monocytogenes

The RPA assay was performed referring to the TwistDx's recommended protocols (http://hdl.handle.net/20.500.11794/26269). The reaction mixture containing $29.5 \mu \mathrm{l}$ of a rehydration buffer, $2.4 \mu \mathrm{l}$ of $10 \mu \mathrm{M}$ forward and reverse primer, $12.2 \mu \mathrm{l}$ of sterile water and $1 \mu 1$ of the template was transferred to a lyophilized pellet tube. Then, $2.5 \mu \mathrm{l}$ of magnesium acetate was added to start the reaction. Sterile water was used as a negative control sample. The tubes were mixed thoroughly and then centrifuged briefly. Subsequently, the tubes were incubated at $39^{\circ} \mathrm{C}$ for $25 \mathrm{~min}$ in BioSan Dry block thermostat Bio TDB-100. A mixing step after 4 min of incubation was carried out for better sensitivity of the assay. Finally, $50 \mu \mathrm{l}$ of PCI was added to the tubes and vortexed lightly. The tubes were centrifuged at $14000 \mathrm{~g}$ for 10 min to remove the undesirable components affecting the read-out of the results. The RPA products were analyzed by a $1.5 \%$ agarose gel electrophoresis and visualized under the UV light using G: BOX Mini 6/9 (Syngene, Cambridge, UK).

Optimization of RPA reaction

According to the manufacturer's guidelines, the effective incubation temperature of TwistAmp Basic kit (https://www.twistdx.co.uk/en/products/product/twistamp-basic) used in this study ranges between $37^{\circ} \mathrm{C}-39^{\circ} \mathrm{C}$. Therefore, to determine the optimal reaction temperature and incubation time of the RPA reaction, the RPA assays were performed at temperatures ranging from $35^{\circ} \mathrm{C}$ to $41^{\circ} \mathrm{C}$ for different times including $15,20,25$ and $30 \mathrm{~min}$. The amount of $31 \mathrm{pg}$ of genomic DNA was used as the template for optimizing the L. monocytogenes RPA assay.

Evaluation of Specificity of RPA assay

The specificity of the RPA reaction was assessed under the optimal temperature and incubation time determined. Cross-reactivity analysis using the extracted genomic-DNAs of other typical foodborne pathogens including $S$. enterica, S. aureus, C. perfringens, B. cereus, and $V$. parahaemolyticus (laboratory collection) was also performed.

\section{Evaluation of LOD of RPA assay}

To evaluate the LOD of the RPA assay, a 10-fold serial dilution from $310 \mathrm{ng}$ to $3.1 \mathrm{fg}$ of the extracted genomic-DNA of L. monocytogenes was prepared. One $\mu 1$ of each DNA concentration was utilized as the template for RPA and PCR assays. The LOD of the RPA reaction was compared with the LOD of the PCR assay.

To determine the LOD of the direct RPA assay, various concentrations of the $L$. monocytogenes cell culture were prepared. $L$. monocytogenes was initially cultured in $10 \mathrm{ml}$ of fresh Brain Heart Infusion broth at $37^{\circ} \mathrm{C}$ for 24 hours. The L. monocytogenes cell concentration was determined using the count plating method. Next, $1 \mathrm{ml}$ of the L. monocytogenes culture was centrifuged at $4000 \mathrm{~g}$ for 20 min at $4^{\circ} \mathrm{C}$ to harvest the cells. The final pellet was washed two times and resuspended in $100 \mu \mathrm{l}$ of $0.9 \% \mathrm{NaCl}$. A serial dilution of the $L$ monocytogenes cells was then prepared to attain samples with a final concentration ranging from $2.5 \times 10^{8}$ to $2.5 \times 10^{0} \mathrm{CFU} / \mathrm{ml}$. Then one $\mu 1$ of each cell concentration was directly utilized as the template for the RPA assay. 
bioRxiv preprint doi: https://doi.org/10.1101/2021.05.22.445288; this version posted May 23, 2021. The copyright holder for this preprint (which was not certified by peer review) is the author/funder, who has granted bioRxiv a license to display the preprint in perpetuity. It is made available under aCC-BY 4.0 International license.

To evaluate the efficiency of RPA assay for the direct detection of $L$. monocytogenes in contaminated milk, the cell pellets harvested from different concentrations of cell cultures were spiked into $1 \mathrm{ml}$ of the pasteurized milk purchased from the local supermarket. The tubes were vortexed and centrifuged at $6000 \mathrm{~g}$ for 3 minutes. Next, $900 \mu 1$ of the upper liquid was removed gently. Then, each sample was used as the template for direct RPA assays.

\section{RESULTS AND DISCUSSION}

\section{RPA assay for detection of L. monocytogenes}

RPA primers were designed to detect the plcA gene of $L$. monocytogenes. The target region is an important virulence gene that has been shown to have high specificity for diagnosing L. monocytogenes strain (Lida et al., 2014). The RPA reactions were performed using $3.1 \mathrm{ng}$ of the genomic DNA of L. monocytogenes as a template. The result showed that the assay produced a clearly visible band at approximately 228 base pairs (bp) of the expected size when analyzed by gel electrophoresis (Fig. 1, lane 4). The size of the amplified product obtained by RPA is similar to the amplicon produced by PCR when using the same primer set (Fig. 1, lane 2), indicating that the RPA primers designed successfully amplified the target sequence as expected.

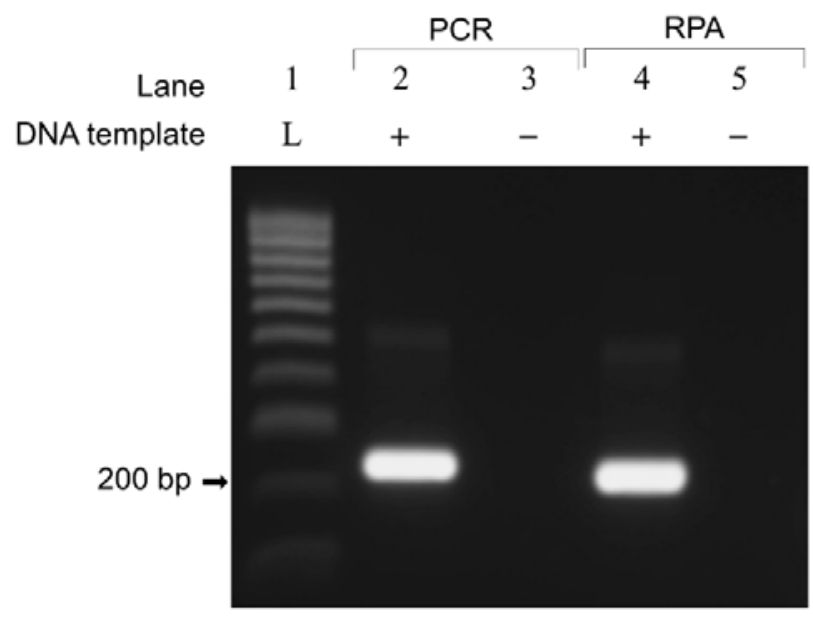

Figure 1. Detection of genomic DNA of L. monocytogenes by RPA and PCR. Positive reactions contain $3.1 \mathrm{ng}$ of the DNA template. Sterile water is used as the negative control sample. Abbreviation, L: DNA ladder.

Optimization of RPA assay for detection of $L$. monocytogenes

The optimal temperature and incubation time of the RPA reaction for the detection of $L$. monocytogenes were determined. The results indicated that the highest amount of amplified product was observed at $39^{\circ} \mathrm{C}$ (Fig. 2A, lane 4). For incubation time, the RPA amplicon could be seen just after $15 \mathrm{~min}$ and got saturation after $25 \mathrm{~min}$ (Fig. 2B). Thus, the optimal condition of the RPA reaction for detection of $L$. monocytogenes genomic DNA was set at $39^{\circ} \mathrm{C}$ for $25 \mathrm{~min}$.

A

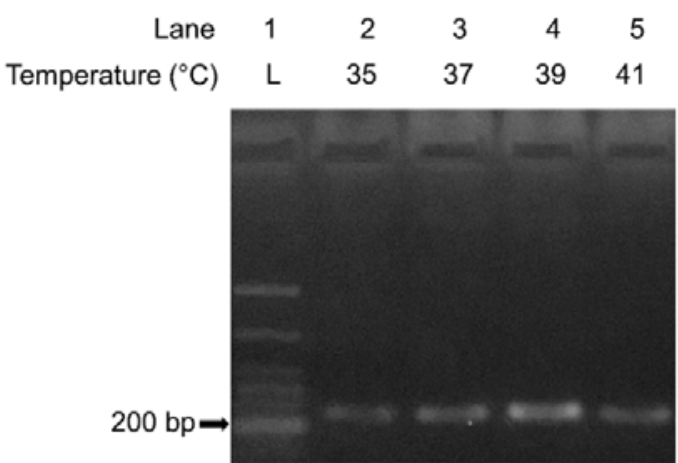

B

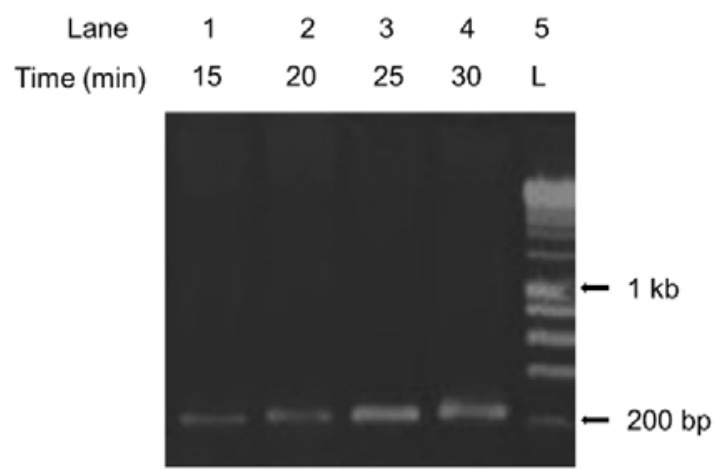

Figure 2. Optimization of the temperature and incubation time of RPA reaction. The reaction contains $31 \mathrm{pg}$ of L. monocytogenes genomic DNA. (A) The RPA reactions were incubated at 35, 37, 39, and $41^{\circ} \mathrm{C}$, respectively. (B) The RPA reactions were incubated at $39{ }^{\circ} \mathrm{C}$ from 15 to 30 min. Abbreviation, L: DNA ladder.

\section{Specificity of RPA assay for detection of $L$. monocytogenes}

In silico PCR analysis showed that the designed primer pair would not amplify the genome sequences of 20 different bacterial strains, supporting that the selected primer set has high specificity for identifying $L$. monocytogenes (Table 2 ). To practically evaluate the specificity of RPA assay developed for detection of L. monocytogenes, genomic DNAs of several bacteria commonly causing food poison were 
bioRxiv preprint doi: https://doi.org/10.1101/2021.05.22.445288; this version posted May 23, 2021. The copyright holder for this preprint (which was not certified by peer review) is the author/funder, who has granted bioRxiv a license to display the preprint in perpetuity. It is made available under aCC-BY 4.0 International license.

extracted and used as the template for RPA reactions. The results indicated that no cross-reactivity was observed with the foodborne bacterial strains examined including $S$. enterica, S. aureus, C. perfringens, B. cereus, and V. parahaemolyticus (Fig. 3). Thus, the RPA primer pair designed is highly specific for L. monocytogenes.

Table 2. In silico PCR results (0-2 mismatch allowed in 3'-end)

\begin{tabular}{|c|c|c|c|}
\hline No & Organism & Primer binding & PCR product \\
\hline 1 & L. monocytogenes & + & + \\
\hline 2 & Bacillus anthracis & - & - \\
\hline 3 & B. cereus & - & - \\
\hline 4 & Campylobacter jejuni & - & - \\
\hline 5 & Candida albicans & - & - \\
\hline 6 & Clostridium botulinum & - & - \\
\hline 7 & C. perfringens & - & - \\
\hline 8 & Escherichia coli & - & - \\
\hline 9 & Leptospira interrogans & - & - \\
\hline 10 & Mycobacterium tuberculosis & - & - \\
\hline 11 & Neisseria meningitidis & - & - \\
\hline 12 & Pseudomonas aeruginosa & - & - \\
\hline 13 & S. enterica & - & - \\
\hline 14 & Shigella sonsei & - & - \\
\hline 15 & S. aureus & - & - \\
\hline 16 & Staphylococcus epidermidis & - & - \\
\hline 17 & Streptococcus pneumoniae & - & - \\
\hline 18 & Streptococcus salivarius & - & - \\
\hline 19 & Vibrio cholerae & - & - \\
\hline 20 & $V \cdot$ parahaemolyticus & - & - \\
\hline 21 & Yersinia pseudotuberculosis & - & - \\
\hline
\end{tabular}

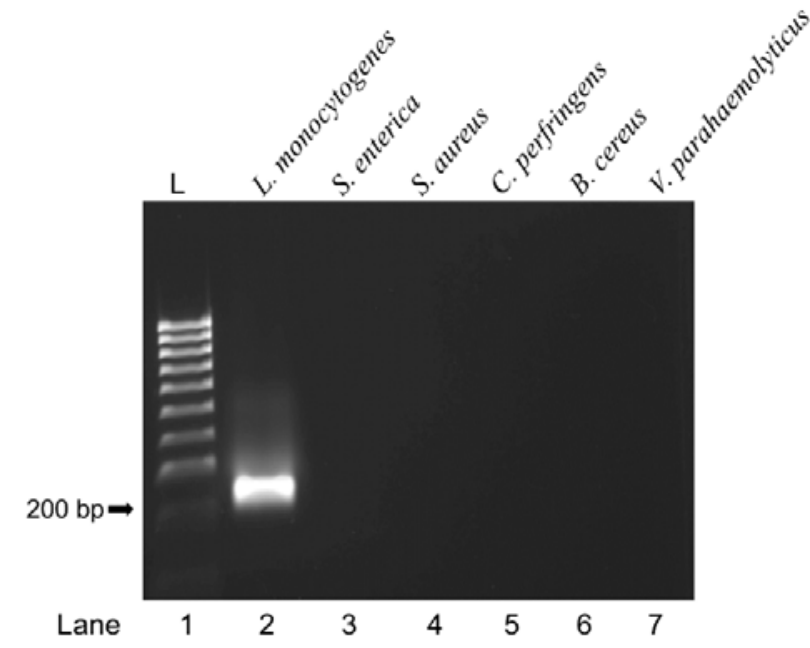

Figure 3. The specificity of L. monocytogenes RPA assay was evaluated with $3.1 \mathrm{ng}$ of genomic DNAs of L. monocytogenes and other foodborne bacteria. Abbreviation, L: DNA ladder.

\section{Detection limit of RPA assay for detection of L. monocytogenes}

Evaluation of the sensitivity of $L$. monocytogenes RPA assay developed was performed using a ten-fold dilution of extracted DNA of $L$. monocytogenes. The results showed that the lowest amount of extracted-genomic DNA that RPA could detect was $310 \mathrm{fg} / \mathrm{reaction}$ which equivalents to 99 genome copies per reaction (Fig. 4A). Meanwhile, the LOD value of PCR utilizing the same primer set was identified at $310 \mathrm{pg} /$ reaction (Fig. 4B). The RPA assay is thus approximately 1000 times more sensitive than the PCR reaction in this study. 
bioRxiv preprint doi: https://doi.org/10.1101/2021.05.22.445288; this version posted May 23, 2021. The copyright holder for this preprint (which was not certified by peer review) is the author/funder, who has granted bioRxiv a license to display the preprint in perpetuity. It is made available under aCC-BY 4.0 International license.

A

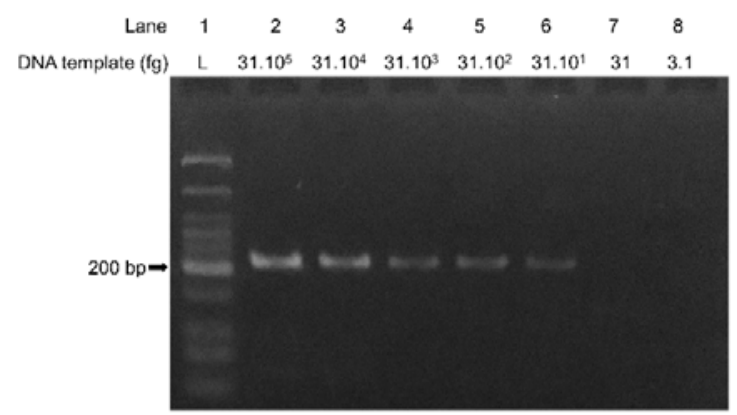

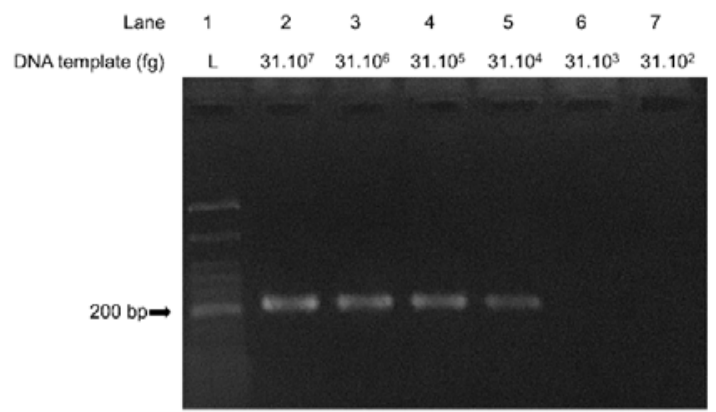

Figure 4. Comparison of the LOD values between RPA and PCR assay for detection of $L$. monocytogenes genomic DNA. The LOD values of RPA (A) and PCR (B) were evaluated using the ten-fold serial dilution of L. monocytogenes genomic DNA extracted ranging from $310 \mathrm{ng}$ to $3.1 \mathrm{fg}$. One $\mu \mathrm{l}$ of each DNA concentration was used for the PCR and RPA reactions, respectively. Abbreviation, L: DNA ladder.

\section{Direct RPA assay for detection of $L$. monocytogenes}

We attempted to detect $L$. monocytogenes cells from unextracted samples by the RPA assay developed. To this end, the cell culture of $L$. monocytogenes was used directly as the template for RPA reactions. As expected, the RPA assay could detect the presence of $L$. monocytogenes genomic DNA without the sample extraction process (Fig. 5A). Next, the LOD of direct RPA for detection of $L$. monocytogenes was determined using the serial dilution of L. monocytogenes cell culture. The results showed that the amplified products could be observed at the cell concentrations ranging from $2.5 \times 10^{6}$ to $2.5 \times 10^{1} \mathrm{CFU} / \mathrm{ml}$ (Fig. 5B). There was no RPA amplicon produced at $2.5 \mathrm{CFU} / \mathrm{ml}$ (Fig. 5B, lane 7). Thus, the LOD of L. monocytogenes direct RPA was determined at $2.5 \times 10^{1} \mathrm{CFU} / \mathrm{ml}$.

A

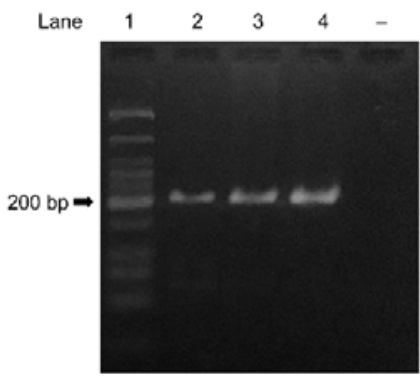

B

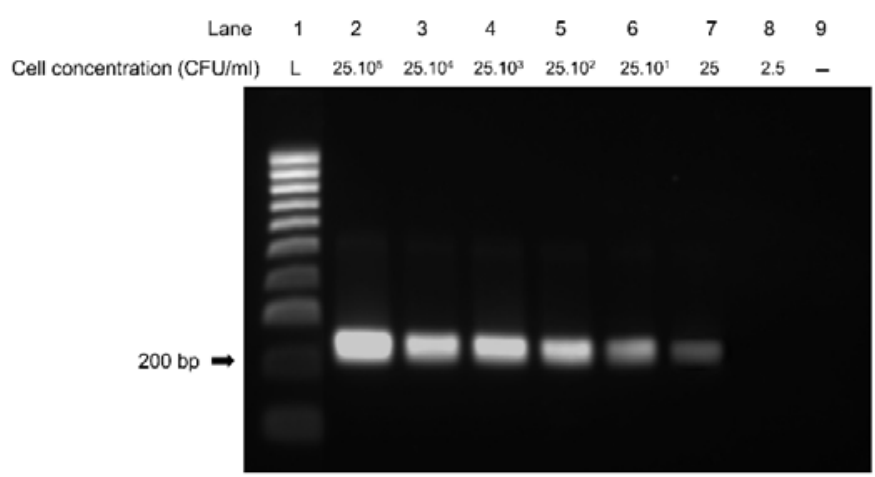

Figure 5. Direct RPA reaction with L. monocytogenes cell culture without DNA extraction. (A) The RPA assays were performed with $1 \mu 1$ of the cell culture (lanes 2 to 4 ). Sterile water was used as the negative control sample. (B) Evaluating the LOD of direct L. monocytogenes RPA using the ten-fold serial dilution of the cell culture. Abbreviation, L: DNA ladder.

\section{Direct detection of $L$. monocytogenes cells by RPA in contaminated milk}

To examine the ability of direct RPA assay using food sample, the artificially contaminated milk was prepared by spiked with $L$. monocytogenes cells at low concentrations ranging from $2.5 \times 10^{2}$ to $2.5 \times 10^{0} \mathrm{CFU} / \mathrm{ml}$. Without the need for DNA extraction or sample processed or cell enrichment, the LOD of direct RPA assay using milk samples was defined at $2.5 \times 10^{2} \mathrm{CFU} / \mathrm{ml}$ (Fig. 6). The LOD value was ten times higher than that of direct RPA using cell culture, indicating that there are certain components in the milk sample interfering with the RPA reaction to some extent. 
bioRxiv preprint doi: https://doi.org/10.1101/2021.05.22.445288; this version posted May 23, 2021. The copyright holder for this preprint (which was not certified by peer review) is the author/funder, who has granted bioRxiv a license to display the preprint in perpetuity. It is made available under aCC-BY 4.0 International license.

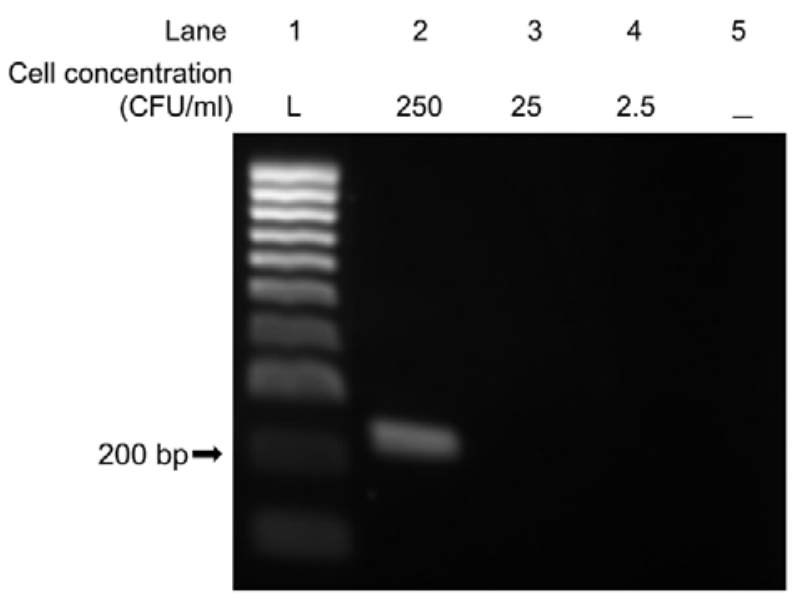

Figure 6. Performance of RPA assays for direct detection of L. monocytogenes in artificially contaminated milk. The RPA reactions were examined using $1 \mu \mathrm{l}$ of the simulated infection milk spiked with different concentrations of $L$. monocytogenes cells ranging from $2.5 \times 10^{2}$ to $2.5 \times 10^{0} \mathrm{CFU} / \mathrm{ml}$. Abbreviation, L: DNA ladder.

\section{DISCUSSION}

L. monocytogenes is one of the common types of food poisoning bacteria which can cause serious foodborne diseases or even lethality. To promptly prevent the serious consequences of $L$. monocytogenes infection, the development of a rapid and efficient method for $L$. monocytogenes detection is needed. Currently, RPA is one of the isothermal amplification techniques that have been applied to detect different infectious bacteria precisely and quickly (Liu et al., 2017; Frimpong et al., 2019; Geng et al., 2019; Hu et al., 2020). In this study, the RPA assay was developed to specifically detect $L$. monocytogenes in direct crude samples.

The RPA amplification efficiency depends on the target sequence, amplicon size, and quality and type of sample tested (Daher $\boldsymbol{e t}$ al., 2016). Most previous studies analyzed the RPA performance using genomic DNA extracted from enrichment solution or using the spiked- $L$. monocytogenes food samples that were boiled or pretreated with lysis buffer to release the DNA (Gao et al., 2017; Du et al., 2018). These steps made the RPA assays previously developed more time-consuming, limiting their application at the field. In this study, we eliminated the genomic DNA extraction and used contaminated milk directly for the RPA reaction. The approach makes the testing handling simpler and faster in the diagnosis of $L$. monocytogenes. The L. monocytogenes RPA assay is advantageous due to no requirement for a specialized thermocycler. The assay could efficiently amplify the target sequence within $25 \mathrm{~min}$ at a low temperature of $39^{\circ} \mathrm{C}$. The short testing time and low incubation temperature are beneficial for the early detection of L. monocytogenes in practical application. These advantages make the RPA assay developed to detect L. monocytogenes time-saving and cost-effective at the field with restricted resources.

The developed RPA assay had high specificity and sensitivity. No cross-reactivity was observed with several bacteria tested, which is in agreement with the previous study. Besides, the method has been proven that it was extremely sensitive compared to the PCR assay in this study. The LOD of the RPA assay was $310 \mathrm{fg}$ of extracted DNA, indicating a 1000-fold higher sensitivity than PCR. Also, the RPA assay could directly detect as low as $25 \mathrm{CFU} / \mathrm{ml}$ of L. monocytogenes cells in medium cultures and $2.5 \times 10^{2} \mathrm{CFU} / \mathrm{ml}$ of L. monocytogenes cells in contaminated milk. The obtained results agree with the previous studies, showing that RPA assays succeeded to directly detect the target bacteria in simulated clinical samples without the need for genomic DNA extraction (Santiago-Felipe et al., 2015; Geng et al., 2019). The reduced sensitivity of RPA observed with milk samples is mostly due to the matrices of crude samples that potentially affect the amplification process (Miao et al., 2019; L. Wang et al., 2020).

In summary, the direct RPA assay developed is a specific and rapid approach to alternate the traditional methods for efficiently and accurately diagnosing $L$. monocytogenes in food. Further evaluation of the assay with different types of crude samples by clinical testing for the diagnosis of $L$. monocytogenes infection, particularly in areas with restricted settings should be performed.

\section{CONCLUSION}

The direct RPA assay which is rapid and sensitive developed in this study could be an alternative method for the diagnosis of $L$. monocytogenes infection, especially in areas with limited resources.

Acknowledgments: This word was funded by NTTU Foundation for Science and Technology Development under grant number 2020.01.015.

\section{REFERENCES}

Carvalho, F., Sousa, S., \& Cabanes, D. (2014). How Listeria monocytogenes organizes its surface for virulence. Frontiers in Cellular and Infection Microbiology, 4, 48. https://doi.org/10.3389/fcimb.2014.00048

Chau, T. T. H., Campbell, J. I., Schultsz, C., van Vinh Chau, N., Diep, T. S., Baker, S., Chinh, N. T., Farrar, J. J., \& Rogier van Doorn, H. (2010). Three adult cases of Listeria monocytogenes meningitis in Vietnam. PLoS Medicine, 7(7), https://doi.org/10.1371/journal.pmed.1000306

Craw, P., \& Balachandran, W. (2012). Isothermal nucleic acid amplification technologies for point-of-care diagnostics: A critical review. Lab on a Chip, 12(14), 2469-2486. https://doi.org/10.1039/c2lc40100b

Craw, P., Balachandran, W., Zanoli, L. M., \& Spoto, G. (2013). Isothermal amplification methods for the detection of nucleic acids in microfluidic devices. Biosensors, 3(1), 18-43. https://doi.org/10.1039/c2lc40100b

Curtis, G. D., \& Lee, W. H. (1995). Culture media and methods for the isolation of Listeria monocytogenes. International Journal of Food Microbiology, 26(1), 1-13. https://doi.org/10.1016/0168-1605(93)e0027-o 
bioRxiv preprint doi: https://doi.org/10.1101/2021.05.22.445288; this version posted May 23, 2021. The copyright holder for this preprint (which was not certified by peer review) is the author/funder, who has granted bioRxiv a license to display the preprint in perpetuity. It is made available under aCC-BY 4.0 International license.

Daher, R. K., Stewart, G., Boissinot, M., \& Bergeron, M. G. (2016). Recombinase Polymerase Amplification for diagnostic applications. Clinical Chemistry, 62(7), 947-958. https://doi.org/10.1373/clinchem.2015.245829

Delibato, E., Gattuso, A., Minucci, A., Auricchio, B., De Medici, D., Toti, L., Castagnola, M., Capoluongo, E., \& Gianfranceschi, M. V. (2009). PCR experion automated electrophoresis system to detect Listeria monocytogenes in foods. Journal of Separation Science, 32(21), 3817-3821. https://doi.org/10.1002/jssc.200900166

Du, X. J., Zang, Y. X., Liu, H. Bin, Li, P., \& Wang, S. (2018). Recombinase Polymerase Amplification combined with Lateral Flow Strip for Listeria monocytogenes detection in food. Journal of Food Science, 83(4), 1041-1047. https://doi.org/10.1111/1750-3841.14078

Frimpong, M., Ahor, H. S., Wahed, A. A. El, Agbavor, B., Sarpong, F. N., Laing, K., Wansbrough-Jones, M., \& Phillips, R. O. (2019). Rapid detection of Mycobacterium ulcerans with isothermal recombinase polymerase amplification assay. PLoS Neglected Tropical Diseases, 13(2), 1-14. https://doi.org/10.1371/journal.pntd.0007155

Gandhi, M., \& Chikindas, M. L. (2007). Listeria: A foodborne pathogen that knows how to survive. International Journal of Food Microbiology, 113(1), 1-15. https://doi.org/10.1016/j.ijfoodmicro.2006.07.008

Gao, W., Huang, H., Zhang, Y., Zhu, P., Yan, X., Fan, J., \& Chen, X. (2017). Recombinase Polymerase Amplification-based assay for rapid detection of Listeria monocytogenes in food samples. Food Analytical Methods, 10(6), 1972-1981. https://doi.org/10.1007/s12161-0160775-0

Geng, Y., Tan, K., Liu, L., Sun, X. X., Zhao, B., \& Wang, J. (2019). Development and evaluation of a rapid and sensitive RPA assay for specific detection of Vibrio parahaemolyticus in seafood. BMC Microbiology, 19(1), 1-9. https://doi.org/10.1186/s12866-019-1562-Z

Göksoy, E. Ö., \& Kaya, O. (2006). Detection of Listeria monocytogenes by using PCR in Helix pomatia. Turkish Journal of Veterinary and Animal Sciences, 30, 375-380.

Hu, J., Wang, Y., Ding, H., Jiang, C., Geng, Y., Sun, X., Jing, J., Gao, H., Wang, Z., \& Dong, C. (2020). Recombinase polymerase amplification with polymer flocculation sedimentation for rapid detection of Staphylococcus aureus in food samples. International Journal of Food Microbiology, 331, 108691. https://doi.org/10.1016/j.ijfoodmicro.2020.108691

Lida, L., Abazar, P., Irajian, G., \& Jamileh, N. (2014). Polymerase chain reaction (PCR4)-based detection of hly and plc-A genes in Listeria monocytogenes isolated from dairy and meat products in Iran. African Journal of Microbiology Research, 8(10), 1098-1101. https://doi.org/10.5897/ajmr2013.6468

Liu, H. bin, Zang, Y. X., Du, X. jun, Li, P., \& Wang, S. (2017). Development of an isothermal amplification-based assay for the rapid visual detection of Salmonella bacteria. Journal of Dairy Science, 100(9), 7016-7025. https://doi.org/10.3168/jds.2017-12566

Liu, W., Dong, D., Yang, Z., Zou, D., Chen, Z., Yuan, J., \& Huang, L. (2015). Polymerase Spiral Reaction (PSR): A novel isothermal nucleic acid amplification method. Scientific Reports, 5, 1-8. https://doi.org/10.1038/srep12723

Miao, F., Zhang, J., Li, N., Chen, T., Wang, L., Zhang, F., Mi, L., Zhang, J., Wang, S., Wang, Y., Zhou, X., Zhang, Y., Li, M., Zhang, S., \& Hu, R. (2019). Rapid and sensitive recombinase polymerase amplification combined with lateral flow strip for detecting African swine fever virus. Frontiers in Microbiology, 10(MAY), 1-7. https://doi.org/10.3389/fmicb.2019.01004

Nathaniel, B. R., Ghai, M., Druce, M., Maharaj, I., \& Olaniran, A. O. (2019). Development of a loop $\square$ mediated isothermal amplification assay targeting lmo0753 gene for detection of Listeria monocytogenes in wastewater. Letters in Applied Microbiology, 69(4), 264-270. https://doi.org/10.1111/lam.13200

Notomi, T., Okayama, H., Masubuchi, H., Yonekawa, T., Watanabe, K., Amino, N., \& Hase, T. (2000). Loop-mediated isothermal amplification of DNA. Nucleic Acids Research, 28(12), E63. https://doi.org/10.1093/nar/28.12.e63

Piepenburg, O., Williams, C. H., Stemple, D. L., \& Armes, N. A. (2006). DNA detection using recombination proteins. PLoS Biology, 4(7), 1115-1121. https://doi.org/10.1371/journal.pbio.0040204

Santiago-Felipe, S., Tortajada-Genaro, L. A., Morais, S., Puchades, R., \& Maquieira, Á. (2015). Isothermal DNA amplification strategies for duplex microorganism detection. Food Chemistry, 174, 509-515. https://doi.org/10.1016/j.foodchem.2014.11.080

Swaminathan, B., \& Gerner-Smidt, P. (2007). The epidemiology of human listeriosis. Microbes and Infection, 9(10), 1236-1243. https://doi.org/10.1016/j.micinf.2007.05.011

Swetha, C. S., Babu, A. J., \& Rao, T. M. (2015). Detection of Listeria monocytogenes in milk and ice cream by polymerase chain reaction. Research \& reviews: Journal of Microbiology and Virology, 5, 1-12.

Taherkhani, A., Attar, H., MM, A., Mirzaee, S. A., \& Jalali, M. (2013). Prevalence of Listeria monocytogenes in the river receiving the effluent of municipal wastewater treatment plant. Int J Env Health Eng, 3, 37-41. https://doi.org/10.4103/2277-9183.122447

Wang, L., Zhao, P., Si, X., Li, J., Dai, X., Zhang, K., Gao, S., \& Dong, J. (2020). Rapid and specific detection of Listeria monocytogenes with an isothermal amplification and Lateral Flow Strip combined method that eliminates false-positive signals from primer-dimers. Frontiers in Microbiology, 10(2), 1-13. https://doi.org/10.3389/fmicb.2019.02959

Wang, Y., Wang, Y., Ma, A., Li, D., \& Ye, C. (2014). Rapid and sensitive detection of Listeria monocytogenes by cross-priming amplification of lmo0733 gene. FEMS Microbiology Letters, 361(1), 43-51. https://doi.org/10.1111/1574-6968.12610

WHO. (2018). Food safety. https://www.who.int/news-room/fact-sheets/detail/food-safety

Xu, G., Hu, L., Zhong, H., Wang, H., Yusa, S. I., Weiss, T. C., Romaniuk, P. J., Pickerill, S., \& You, Q. (2012). Cross priming amplification: Mechanism and optimization for isothermal DNA amplification. Scientific Reports, 2, 1-7. https://doi.org/10.1038/srep00246 